\title{
COMPARATIVE TEMPORAL DISCOLOURATION OF DRY MUSEUM SPECIMENS OF MOUNTAIN BLACKEYE (Chlorocharis emiliae)
}

\author{
MOHAMAD FIZL SIDQ RAMJ* \& MUSTAFA ABDUL RAHMAN \\ Department of Zoology, Faculty of Resource Science and Technology, \\ Universiti Malaysia Sarawak 94300, Kota Samarahan, Sarawak
}

\begin{abstract}
Plumage colour studies using museum skins is one of the ways to understand species evolution and plumage polymorphism. The invaluable scientific information on a single historic specimen should be well-presented in the most regarded form of quality skin. However, aging plumage feathers are hypothetically susceptible to colour fading therefore doubting the relevant of using old specimens for plumage colour assessment. We examined the colour changes in 36 museum specimens by conducting series of Munsell colour scoring by comparing recent and old skins of mountain blackye (Chlorocharis emiliae), at Universiti Malaysia Sarawak (UNIMAS) and Sarawak Museum (SM). The year-gap of both sets of specimens ranged from 52 to 75 years. Eight plumage characters included in this study were crown, supercilium, auricular, mantle, rump, breast, belly and vent. The results revealed that the head (crown and auricular) and underparts (breast and vent) tend to fade extensively overtime compared to the upperparts. Therefore the results of this study support the earlier findings that aging plumage feathers are susceptible to colour fading.
\end{abstract}

Keywords: plumage, museum specimens, colour scoring, fading, mountain blackeye

\section{INTRODUCTION}

Over the years, several studies had shown significant evidence of discolouration on museum specimens. Armenta et al. (2008) highlighted that museum specimens collected within the 50 years-mark were adequately robust for colour and plumage observations in birds. Conversely, specimens exceeding 50 years since the collection date were more vulnerable to degradation of colour pigments in the feathers. The renewed interest in the study of animal colouration has triggered interest for numerous researches to focus on the evolution of bird plumage colouration (Grande et al. 2004). Winker (2000) expressed concern over the importance of preparing archival-quality skins to retain the scientific values and elude colour degrading on aging skins. The latest advancement in animal colour research introduced objective methods such as reflectance spectrophotometer and digital imaging. Although these highly accurate techniques are obvious "winners" in plumage colour measurement, it is beneficial to emphasize on the fundamental concepts in colour. Standard colour charts such as the Munsell colour system are well-established and considerably influential in terms of providing options to users by ensuring simple application, practically and cost-wise effective. The rationale of choosing this method was essentially to concur with these objective methods. Such findings were described by Grill and Rush (2000) and Bolund (2009). This study attempts to determine the extent of discolouration of mountain blackeye dry skin specimens using standard colour charts.

The mountain blackeye (Chlorocharis emiliae) is an excellent model species to illustrate evolution and speciation. Due to its endemic status and only occur on major mountain tops of Borneo, the species had attracted much interest by past and recent researchers, for example diet, behavioural and ecological study by Harrison (1955) and Steinheimer (1999). Generally, mountain blackeye is grouped into the huge family of Zosteropidae (the white eyes) (Mackinnon \& Phillips 1993; Smythies 1999). The current taxonomic classification recognized four subspecies of mountain blackeye; $C$. e. emiliae (Sharpe 1888) from Mt. Kinabalu, C. e. trinitae (Harrison 1956) from Mt. Trus Madi, C. e. moultoni (Chasen \& Kloss 1927) from Mt. Murud, Mt. Mulu, Mt. Poi and Tama Abo Range and the fourth subspecies, C. e. fusciceps (Mees 1954) from Mt. Maga. (Gawin \& Rahman 2005) further validated the variation in mountain blackeye based on genetic and morphological characters. 
The definitive feature of mountain blackeye can be characterized by a conspicuous black orbital ring edged with light yellowish green on the supercilium and jugulum of the head (Davison 2001). These titlike birds varied in terms of plumage colouration of the underparts from a range of olive-greens and yellows (Smythies 1999). Although the plumage complexities were apparent in each subspecies, they were documented as having distinctive plumage features by subjective interpretations of greenness, yellowness and relative darkness of blackish tone (Table 1). Mountain blackeye were also noted to possess monomorphic colouration on both sexes (Mees 1955). In 1955, Mees reviewed on the plumage colour of $C$. emiliae skins taken by early Sarawak Museum collectors. He speculated that colour degradation was evident on earlier specimens prior to their collection dates. Latest collections by Harrison in 1952 featured the blackest crown followed by slightly browner crown found in specimens collected by Harvard Primate Expedition in 1937. Holotype specimens by Whitehead (1888) displayed distinguished green crown compared to both recent specimens. Thus, Mees (1955) concluded that melanin pigments degraded over time with specimen age.

Table 1: Plumage and body parts colouration in Cholorocharis emiliae

\begin{tabular}{|c|c|c|c|c|}
\hline Body part & $\begin{array}{l}\text { C. e. emiliae } \\
\text { (Sharpe 1888) }\end{array}$ & $\begin{array}{c}\text { C. e. trinitae } \\
\text { (Harrison 1956) }\end{array}$ & $\begin{array}{c}\text { C. e. moultoni } \\
\text { (Chasen \& Kloss 1927) }\end{array}$ & $\begin{array}{l}\text { C. e. fusciceps } \\
\text { (Mees 1954) }\end{array}$ \\
\hline \multicolumn{5}{|l|}{ Head } \\
\hline Crown & Blackish & Crown not dark as & Slightly darker than mantle & Dark sephia (darker \\
\hline Forehead & $\begin{array}{l}\text { Part yellowish/part } \\
\text { blackish }\end{array}$ & $\begin{array}{l}\text { fusciseps but similiar to } \\
\text { emiliae }\end{array}$ & yellower & than emiliae. \\
\hline Supercilium & $\begin{array}{l}\text { Yellow/dark and ill- } \\
\text { defined }\end{array}$ & Distinct but moderate & $\begin{array}{l}\text { Conspicuous broad } \\
\text { yellow/yellower than } \\
\text { emiliae }\end{array}$ & - \\
\hline Auricular & Dark green cheeks & Yellow cheeks & & - \\
\hline \multicolumn{5}{|l|}{ Upperparts } \\
\hline Mantle & Dark olive green & Olive green & Less green and duller than & Intermediate \\
\hline Rump & $\begin{array}{l}\text { Less dark,brighter than } \\
\text { mantle }\end{array}$ & - & emiliae & $\begin{array}{l}\text { between emiliae } \\
\text { and moultoni } \\
\text { (Banks, 1952) }\end{array}$ \\
\hline \multicolumn{5}{|l|}{ Underparts } \\
\hline Throat & $\begin{array}{l}\text { Pale yellowish green } \\
\text { (Davison,1998) }\end{array}$ & Pale green to yellowish & Light green & $\begin{array}{l}\text { Agrees almost } \\
\text { entirely with } \\
\text { moultoni }\end{array}$ \\
\hline
\end{tabular}

\section{MATERIALS \& METHODS}

\section{Specimens examined}

A total of 36 dry museum skins of mountain blackeye were assessed to compare plumage colouration and the degree of fading overtime. The skins were acquired from two museum depositories namely Museum of Zoology UNIMAS (MZU) and Sarawak Museum (SM). Specimens were categorized as "recent" for 25 MZU fresh specimen sampled within one year period (13 February 2008 to 12 February 2009) and "old" for $11 \mathrm{SM}$ specimen collected between 14 August 1934 and 29 August 1956 (Table 2). The year-gap between both collections ranged from 52 to 75 years, exceeding the 50 years cutoff age for the "old" definition suggested by Armenta et al. (2008). It is important to note that only fine and average skins were selected for the plumage assessment as poorly-graded skins would greatly affect its natural plumage colour. All MZU study skins were prepared based on the guidelines by Proctor \& Lynch (1993) and Winker (2000).

\section{Plumage colour assessments}

Plumage colours were scored using Munsell Book of Colour (Glossy finish collection; Gretag Macbeth LLC). The Munsell system of colour notation decodes a single colour into three dimensions; Hue $(\mathrm{H})$ specifying the attribute of a colour (red, yellow, green, blue, purple etc.); Value (V) indicating the darkness and lightness of the colour (ranging from 0 : very dark to 10: Very Light); Chroma (C) describing the intensity of the colour (ranged from very saturated/weak to very intense/vivid/strong). The 
formal notation for describing a particular colour is written as HV/C, for example; 7.5H 6/10 describing a colour with a hue of 7.5 yellow, a moderate value of 6 and a very intense chroma of 10 (Table 3). Plumage observation and colour scoring were standardized by using one person to record data for every session, similar to techniques described by Miskimen (1980), Burley et al. (1992), Vanderwerf (2001) and Bostrom \& Ritchison (2006). The scoring task was conducted under controlled environment and consistent lighting (ample daylight/cloud-free). This is to avoid illuminant (metamerasim) during colour matching (Wood \& Wood 1972).

Appropriate Munsell colour chips were matched to the following eight plumage characters; crown, supercilium, auricular, mantle, and rump, breast, belly and vent. For multiple colouration in plumage region such as on the belly, colour is determined by considering the most dominant colour with the largest surface area. Both MZU and SM specimens were scored on separate sessions with three series of repetitions. The means were obtained from the scores of the overall dataset. Munsell value and chroma were used directly in the analysis, but the scores for hue were initially transformed to a numerical scale $(10 \mathrm{YR}=0,2.5 \mathrm{Y}=1,5 \mathrm{Y}=2,7.5=$ $3,10 \mathrm{Y}=4)$. Discriminant function analysis (DFA) was performed for the scored characters by assigning the specimens as grouping variables (specimen holders). Data were analyzed using SYSTAT 12 (2007) statistical software.

Table 2: Detailed listings of MZU and SM specimens

\begin{tabular}{|c|c|c|c|c|c|c|}
\hline No. & Sample & Sex & Sampling Site & Collection Date & GPS & $\begin{array}{l}\text { Elevation (asl; } \\
\text { meters) }\end{array}$ \\
\hline 01 & MD01 & F & Mt. Murud & 29 Oct 2008 & N $03^{\circ} 55.645^{\prime}$ E $115^{\circ} 30.676^{\prime}$ & 2113 \\
\hline 02 & MD02 & M & Mt. Murud & 29 Oct 2008 & N03 $55.645^{\prime}$ E $115^{\circ} 30.676^{\prime}$ & 2113 \\
\hline 03 & MD03 & $\mathrm{F}$ & Mt. Murud & 29 Oct 2008 & N $03^{\circ} 55.645^{\prime}$ E $115^{\circ} 30.676^{\prime}$ & 2113 \\
\hline 04 & MD04 & - & Mt. Murud & 31 Oct 2008 & N $03^{\circ} 55.645^{\prime}$ E $115^{\circ} 30.676^{\prime}$ & 2113 \\
\hline 05 & ML01 & - & Mt. Mulu & 6 Feb 2009 & N $04^{0} 02.694^{\prime}$ E $114^{0} 54.651^{\prime}$ & 1764 \\
\hline 06 & ML02 & - & Mt. Mulu & 6 Feb 2009 & N $04^{0} 02.694^{\prime}$ E $114^{0} 54.651^{\prime}$ & 1764 \\
\hline 07 & ML03 & - & Mt. Mulu & 6 Feb 2009 & N $04^{0} 02.694^{\prime}$ E $114^{0} 54.651^{\prime}$ & 1764 \\
\hline 08 & ML04 & - & Mt. Mulu & 6 Feb 2009 & N $04^{0} 02.694^{\prime}$ E $114^{0} 54.651^{\prime}$ & 1764 \\
\hline 09 & ML05 & - & Mt. Mulu & 9 Feb 2009 & N $04^{0} 02.694^{\prime}$ E $114^{0} 54.651^{\prime}$ & 1764 \\
\hline 10 & KK14 & - & Mt. Kinabalu & 20 Feb 2008 & N 0602.676' E $116^{0} 33.795^{\prime}$ & 2691 \\
\hline 11 & KK16 & - & Mt. Kinabalu & 20 Feb 2008 & N 060․․676' E $116^{0} 33.795^{\prime}$ & 2691 \\
\hline 12 & KK12 & - & Mt. Kinabalu & 20 Feb 2008 & N 060202.676' E 116 $33.795^{\prime}$ & 2691 \\
\hline 13 & KK26 & - & Mt. Kinabalu & 21 Feb 2008 & N 0602.676' E $116^{0} 33.795^{\prime}$ & 2691 \\
\hline 14 & KK15 & - & Mt. Kinabalu & 20 Feb 2008 & N 0602.676' E $116^{0} 33.795^{\prime}$ & 2691 \\
\hline 15 & TM01 & $\mathrm{F}$ & Mt.Trus Madi & 11 July 2008 & N $05^{0} 33.453^{\prime}$ E $116^{0} 30.362^{\prime}$ & 2368 \\
\hline 16 & TM02 & $\mathrm{M}$ & Mt.Trus Madi & 10 July 2008 & N $05^{0} 33.453^{\prime}$ E $116^{0} 30.362^{\prime}$ & 2368 \\
\hline 17 & TM03 & $\mathrm{F}$ & Mt.Trus Madi & 10 July 2008 & N $05^{0} 33.453^{\prime}$ E $116^{0} 30.362^{\prime}$ & 2368 \\
\hline 18 & TM04 & M & Mt.Trus Madi & 11 July 2008 & N $05^{0} 33.453^{\prime}$ E $116^{0} 30.362^{\prime}$ & 2368 \\
\hline 19 & TM05 & M & Mt .Trus Madi & 10 July 2008 & N $05^{0} 33.453^{\prime}$ E $116^{0} 30.362^{\prime}$ & 2368 \\
\hline 20 & TM06 & M & Mt.Trus Madi & 10 July 2008 & N $05^{0} 33.453^{\prime}$ E $116^{0} 30.362^{\prime}$ & 2368 \\
\hline 21 & TM07 & $\mathrm{F}$ & Mt .Trus Madi & 11 July 2008 & N $05^{0} 33.453^{\prime}$ E $116^{0} 30.362^{\prime}$ & 2368 \\
\hline 22 & TM08 & M & Mt.Trus Madi & 11 July 2008 & N $05^{0} 33.453^{\prime}$ E $116^{0} 30.362^{\prime}$ & 2368 \\
\hline 23 & TM09 & $\mathrm{M}$ & Mt.Trus Madi & 11 July 2008 & N $05^{0} 33.453^{\prime}$ E $116^{0} 30.362^{\prime}$ & 2368 \\
\hline 24 & TM10 & M & Mt.Trus Madi & 10 July 2008 & N $05^{0} 33.453^{\prime}$ E $116^{0} 30.362^{\prime}$ & 2368 \\
\hline 25 & TM11 & $\mathrm{F}$ & Mt .Trus Madi & 10 July 2008 & N $05^{0} 33.453^{\prime}$ E $116^{0} 30.362^{\prime}$ & 2368 \\
\hline
\end{tabular}




\begin{tabular}{lllcccc}
26 & SMMG01 & M & Mt. Maga & 1 March 1939 & $4^{0} 20^{\prime} \mathrm{N} 115^{\circ} 50^{\prime} \mathrm{E}$ & - \\
27 & SMMG02 & F & Mt. Maga & 1 March 1939 & $4^{0} 20^{\prime} \mathrm{N} 115^{\circ} 50^{\prime} \mathrm{E}$ & - \\
28 & SMML01 & F & Mt. Mulu & 14 Aug 1934 & - & 1981 \\
29 & SMML02 & F & Mt. Mulu & 16 June 1935 & - & $1828-2134$ \\
30 & SMPH01 & M & Poi Range & 18 Aug 1936 & $1^{0} 30^{\prime} \mathrm{N} 110^{\circ} \mathrm{E}$ & $1219-1524$ \\
31 & SMPH02 & F & Poi Range & 16 Aug 1936 & $1^{0} 30^{\prime} \mathrm{N} 110^{\circ} \mathrm{E}$ & $1219-1524$ \\
32 & SMTA & M & Tama Abo Range & 18 Apr 1936 & - & 1372 \\
33 & SMTM01 & M & Mt.Trus Madi & 26 Aug 1956 & - & 2377 \\
34 & SMTM02 & F & Mt.Trus Madi & 29 Aug 1956 & - & 2377 \\
35 & SSMKK01 & M & Mt. Kinabalu & 6 Feb 1952 & - & 3353 \\
36 & SMKK02 & F & Mt. Kinabalu & 6 Feb 1952 & - & 3353 \\
\hline
\end{tabular}

Key : “”” = sex unknown

\section{RESULTS}

\section{General plumage description}

When comparing old specimens against fresh specimens, the old skins were slightly worn and likely to expose drab colouring on the tip of feathers (grey, dull-brownish look). To some extent, the supercilium and blackeye lores does not exhibit putative textures of well-defined ring and were potentially prone to colour fading. Furthermore, feather arrangements appeared aberrant, pale and less natural. In contrast, the recent skins were appealing through its fresh colouration and perfectly-outlined plumage criteria.

\section{Plumage colour analysis}

Based on Figure 1, DFA clearly separate all 36 specimens into two distinct clusters. There was no overlap of hue between both specimen holders. Hue scores of SM specimens ranged from two hue yellow sheets; $2.5 \mathrm{Y}$ and $5 \mathrm{Y}$ while all MZU specimens consistently scored at 7.5Y. The value and chroma scale for MZU specimens were considerably larger, ranging from 2 to 8 and 2 to 11, respectively.

On the other hand, SM specimens revealed smaller range for value (3 to 7) and chroma (4 to 10). The statistical values are as follows; Hue ( $\mathrm{F}=231.64$, $\mathrm{df}=7, \mathrm{P}=0)$, value $(\mathrm{F}=0.429, \mathrm{df}=7, \mathrm{P}=0.884)$ and chroma ( $\mathrm{F}=0.327, \mathrm{df}=7, \mathrm{P}=0.942)$. To make qualitative interpretation of the colour scores simpler, we used a simple colour index to standardize the colour readings (Table 3). The crown area showed drastic decrease in amount of very dark olive-green;
$7.5 \mathrm{Y} 3 / 3$ to $2.5 \mathrm{Y} 3 / 4$ describing a fading dark/saturated deep yellow to dark/saturated pale yellow. The followings are colour index descriptions for other plumage characters; Supercilium = moderate/very intense deep yellow topure yellow, Auricular $=$ moderate/very intense deep yellow to moderate/intense pale yellow, Mantle = dark/saturated deep yellow to dark/saturated pure yellow, Rump = dark/moderate deep yellow to dark/moderate pure yellow, Breast = moderate/intense deep yellow to moderate/moderate pale yellow, Belly $=$ moderate/very intense deep yellow to moderate/very intense pure yellow, Vent = light/very intense deep yellow to moderate/very intense pale yellow (Table 4).

\section{Colour-age relationships}

Specimen age was determined by calculating the number of years between the specimen collection date and date of scoring. The average age of MZU and SM specimens are $0.95 \pm 0.1$ years and $66.18 \pm 9.08$ years respectively, while the average year-gap between both sets of specimens was approximately 65 years. Based on the colour-age linear graphs (Figure 2), specimen age was significantly correlated with hue $(\mathrm{r}=-0.995, \mathrm{p}=$ $0.000)$ while value $(r=-0.206, p=0.227)$ and chroma $\quad(r=-0.226, p=0.184) \quad$ effects were diminutive against time. Hue dramatically decreased by two steps, from $7.5 \mathrm{Y}$ to $2.5 \mathrm{Y}$ suggesting degradation of colour pigments overtime on all plumage regions particularly on the crown, auricular, breast and vent. 


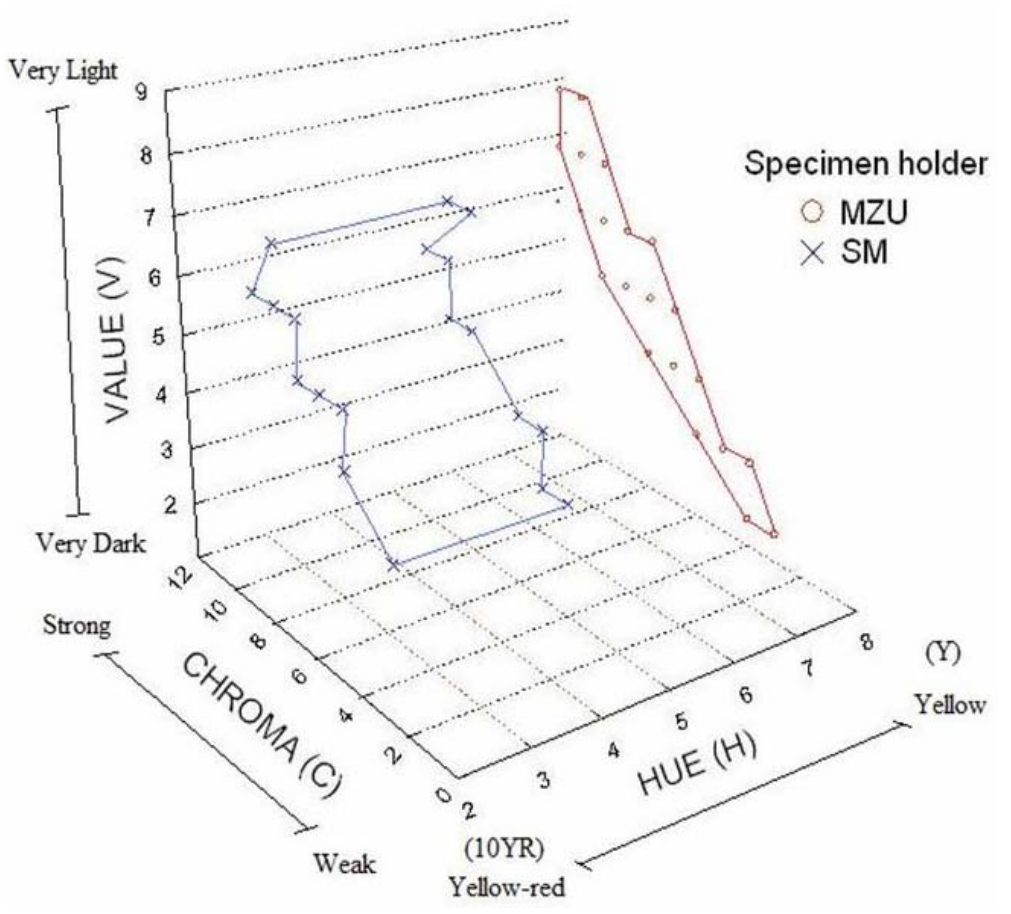

Figure 1. Scatterplot generated clear groupings of MZU and SM specimens as displayed in a modified 3-dimensional colour space.

\section{DISCUSSION}

Plumage colouration is strongly correlated with colour pigments. Most bird plumage consists of three primary substances which includes melanins (black, grey, brown), carotenoids (intense red and yellow) and prophyrins (red, brown and vivid green). In relation to mountain black eye, the crown, mantle and rump including fliht feathers on the wing and tail are visually dark olive green while the underparts displayed blends of bright and intense yellow/yellowish green. It was suggested that melanin and carotenoid were involved directly in the plumage of mountain blackeye.

This finding supports Proctor \& Lynch (1993) which suggested melanins are fundamental and frequent in plumage feathers (usually on the upper parts). Carotenoids were commonly influenced by diet of the species (Price et al. 2006). For instance,the diet of mountain blackeye consist mainly of brightly coloured rhododendrons, yellow nectars of Schima wallichii and red fleshy fruits of rubus berries. Another type of colour pigment associated with the yellow-green complexity on the belly was probably caused by structural pigments produced by combinations of yellow carotenoids and black melanins.

The head (crown and auricular) and underparts (breast and vent) faded more compared to theupperparts. The decrease in hue (7.5Y to $2.5 \mathrm{Y}$ ) on the old specimens was adjacent to 10YR (yellowred).

This somehow revealed the colouration of yellow with rusty and drab appearance. Several factors potentially attributed to colour fading in these areas were subject to handling, preparation and storage condition of specimens. Bird skins are highly vulnerable to biodeterioration due to activities of organism (Allsopp et al. 2004). Grande et al. (2004) discussed with details the implication and role of feather-degrading bacteria in museum specimens. The SM specimens were possibly affected by similar threats considering the storage condition of the specimen. The over exposure of the head and underparts to humidity and bacterial infections are presumably characterized by the common practice of laying specimen with the underparts facing upwards. Similar findings were reported by Armenta et al. (2008). 
Table 3: Munsell hue, value and chroma index description

\begin{tabular}{|c|c|c|c|c|c|}
\hline \multicolumn{2}{|l|}{ Hue } & \multicolumn{2}{|c|}{ Value } & \multicolumn{2}{|c|}{ Chroma } \\
\hline$S^{a}$ & D & $\mathrm{S}$ & D & S & D \\
\hline $10 \mathrm{Y} / 0 \mathrm{GY}$ & $\begin{array}{l}\text { Near Yellow- } \\
\text { green (4) }\end{array}$ & 10 & $\begin{array}{l}\text { Very Light/pure white } \\
\text { (VL) }\end{array}$ & $\begin{array}{l}>10 \\
10 \\
9\end{array}$ & $\begin{array}{l}\text { Very } \\
\text { Intense/vivid/Strong } \\
\text { (VI) }\end{array}$ \\
\hline $7.5 \mathrm{Y}$ & Deep Yellow (3) & $\begin{array}{l}8 \\
7\end{array}$ & Light (L) & $\begin{array}{l}8 \\
7\end{array}$ & Intense (I) \\
\hline $5 \mathrm{Y}$ & Pure Yellow (2) & $\begin{array}{l}6 \\
5\end{array}$ & Moderate (M) & $\begin{array}{l}6 \\
5\end{array}$ & Moderate (M) \\
\hline $2.5 \mathrm{Y}$ & Pale Yellow (1) & $\begin{array}{l}4 \\
3\end{array}$ & Dark (D) & $\begin{array}{l}4 \\
3\end{array}$ & Saturated(S) \\
\hline $10 \mathrm{YR} / 0 \mathrm{Y}$ & Yellow-Red (0) & $\begin{array}{l}2 \\
1\end{array}$ & $\begin{array}{l}\text { Very Dark/ pure black } \\
\text { (VD) }\end{array}$ & $\begin{array}{l}2 \\
1\end{array}$ & $\begin{array}{l}\text { Very } \\
\text { Saturated/Weak } \\
\text { (VS) }\end{array}$ \\
\hline
\end{tabular}

$\overline{\mathrm{S}=\text { Score} ; \mathrm{D}=\text { Description }}$
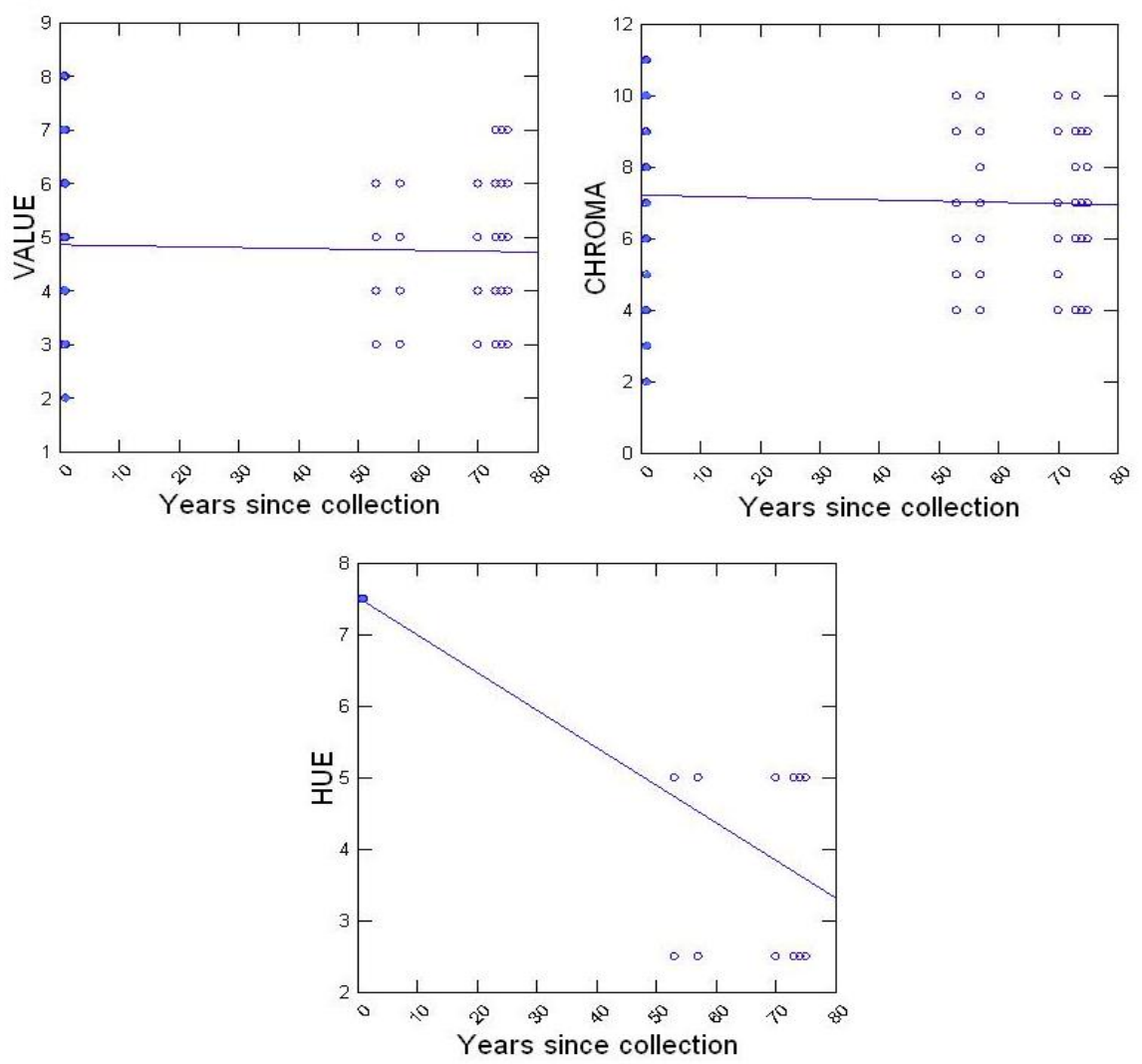

Figure 2. Comparison of hue, value and chroma of both specimens overtime. Closed circles epresent MZU specimens while open circles for SM specimens (linear fit shown). 
Table 4: Colour scores for each plumage characters were given in mean \pm SD

\begin{tabular}{ccccccc}
\hline $\begin{array}{l}\text { Plumage } \\
\text { Character }\end{array}$ & MZU & Hue & MZU & SM & MZU & SM \\
\hline Crown & $7.5 \mathrm{Y}$ & $2.5 \mathrm{Y}$ & $2.68 \pm 0.56$ & 3 & $3.4 \pm 1$ & 4 \\
& & & $(2-4)$ & & $(2-6)$ & \\
Supercilium & $7.5 \mathrm{Y}$ & $5 \mathrm{Y}$ & $6 \pm 0.5$ & $5.73 \pm 0.47$ & $9.76 \pm 1.01$ & $9.78 \pm 0.47$ \\
& & & $(5-7)$ & $(5-6)$ & $(7-11)$ & $(9-10)$ \\
Auricular & $7.5 \mathrm{Y}$ & $2.5 \mathrm{Y} \pm 0.47$ & $5.32 \pm 0.56$ & $5.45 \pm 0.52$ & $8.64 \pm 1.11$ & $8.36 \pm 1.43$ \\
& & $(2.5 \mathrm{Y}-5 \mathrm{Y})$ & $(4-6)$ & $(5-6)$ & $(6-10)$ & $(7-10)$ \\
Mantle & $7.5 \mathrm{Y}$ & $5 \mathrm{Y}$ & 3 & 3 & 4 & 4 \\
Rump & $7.5 \mathrm{Y}$ & $5 \mathrm{Y}$ & $3.96 \pm 0.45$ & $3.81 \pm 0.4$ & $5.76 \pm 0.44$ & $5.55 \pm 0.52$ \\
& & & $(3-5)$ & $(3-4)$ & $(5-6)$ & $(5-6)$ \\
Breast & $7.5 \mathrm{Y}$ & $2.5 \mathrm{Y}$ & $4.92 \pm 0.4$ & $4.55 \pm 0.52$ & $7.52 \pm 0.71$ & $6.36 \pm 0.5$ \\
& & & $(4-6)$ & $(4-5)$ & $(6-9)$ & $(6-7)$ \\
Belly & $7.5 \mathrm{Y}$ & $5 \mathrm{Y}$ & $6.08 \pm 0.76$ & $6.18 \pm 0.75$ & $9.4 \pm 1.15$ & $9 \pm 0.77$ \\
& & & $(4-8)$ & $(5-7)$ & $(7-11)$ & $(8-10)$ \\
Vent & $7.5 \mathrm{Y}$ & $2.5 \mathrm{Y} \pm 0.52$ & $7.04 \pm 0.73$ & $6.09 \pm 0.3$ & $9.44 \pm 0.91$ & $8.9 \pm 0.7$ \\
& & $(2.5 \mathrm{Y}-5 \mathrm{Y})$ & $(6-8)$ & $(6-7)$ & $(7-11)$ & $(8-10)$ \\
\hline
\end{tabular}

The results of matching feathers reflect human subjective perception towards plumage colour. It is critical to emphasize on the subjectivity and limitations of human colour system whereby even under controlled parameters such as identical lighting conditions, such as full sunlight or artificial light, the results of colour scoring by different human observers would regularly produced inconsistency and bias colour data (Endler 1990; Stevens 2009). In this study, this was minimized by regularly having only one person and controlled parameters to conduct the colour scoring in three separate sessions, thus improving scoring accuracy. Furthermore, Bennett et al. (1994) debated earlier hypothesis of birds perceiving colour equally as human. He stated that birds appeared to be UV sensitive and probably tetra chromatic. Consequently, the introduction of reflectance spectrophotometers persuades more researchers to focus on more objective techniques as it gradually becomes affordable. In support of Stevens et al. (2009), the current study assents that colour charts should only be a recommended option for plumage colour assessment if objective methods are not available. However, conventional colour charts are still relevant considering its uncomplicated and practical approach. Hence, we encourage the use of Munsell charts to describe plumage colour of museum skins by providing colour notation associated with subjective colour interpretation on the specimen label. To enhance accuracy, we firmly suggest repetitive test to be incorporated by ascertaining reliability of regular human observers and uniform time measurement of data collection.

\section{ACKNOWLEDGEMENT}

The authors would like to thank Dr. Charles Leh of the Sarawak Museum Department for allowing us to examine Sarawak Museum specimens. Thank you to Mr. Isa Sait, staff and colleagues at Department of Zoology, FRST, UNIMAS for their help and support. This study was funded by the Ministry of Higher Education Malaysia under the Fundamental Research Grant Scheme, Project no: FRGS/06(03)/647/2007(12).

\section{REFERENCES}

Allsopp, D., Seal, K.J. \& Gaylarde, C.C. (2004). Introduction to biodeterioration. $2^{\text {nd }}$ edition. Cambridge : Cambridge University Press, pp. 233

Armenta, J.K., Dunn, P.O. \& Whittingham, L.A. (2008). Effects of specimen age on plumage colour. The Auk, 125: 803-808.

Bennett, A.T.D., Cuthill, I.C., Partridge, J.C. \& Norris, K.J. (1994). Sexual selection and the mismeasure of colour. American Naturalist, 144: 848-860.

Bolund, E. (2009). Condition dependence and fitness consequences of sexual traits in zebra finches. Seewiesen, Germany, pp. 127

Bostrom, M. R. \& Ritchison, G. (2006). Possible relationships between morphology, territory quality, and skin color of American Kestrels. Journal of Field. Ornithology, 77:392-398. 
Burley, N.T., Price, D.K. \& Zann, R.A. (1992). Bill colour reproduction and condition effects in wild and domesticated zebra finches. The Auk, 109: 1323.

Davison G.W.H. (2001). Birds of Mount KinabaluBorneo. Kota Kinabalu: Natural History Publications (Borneo) Sdn. Bhd. And Koktas Sabah Berhad, Sabah. pp. 146

Gawin, D.F.A. \& Rahman, M.A. (2005a). Analysis of external morphological characters in determining patterns of variation among Mountain Blackeye (Chlorocharis emiliae) populations in Borneo. In A. A. Tuen \& I. Das (Eds), Wallace in Sarawak-150 years later. Proceedings of an International Conference on Biogeography and Biodiversity, July 13-15, (pp. 188-194) Kota Samarahan, Malaysia : Institute of Biodiversity and Environmental Conservation, University Malaysia Sarawak. PhD. thesis, Max Planck Institute of Ornithology,

Gawin, D.F.A. \& Rahman, M.A. (2005b). Genetic variation among mountain blackeye (Chlorocharis emiliae) populations in Borneo. In L. Seng (ed). Proceedings of the International Conference on Natural Resources and Environmental Management. Sarawak Development Institute, pp. 395-404.

Gill, F.B. (1990). Speciation. Ornithology. New York. : W H. Freeman and Company, pp. 661

Gomez, D. \& Voisin, J. (2002). Spectrometry validates subspeciation in the Kerguelen tern Sterna Virgata. Marine Ornithology, 30:19- 24.

Grande, J. M., Negro, J. J. \& Torres, M.J. (2004). The evolution of bird plumage colouration: A role for feather -degrading bacteria? Ardeola 51: 375-383.

Grill, C.P. \& Rush, V.N. (2000). Analyzing spectral data: comparison and application of two techniques. Biological Journal of the Linnean society, 69: 121-138.

Harrison, T. (1955). The mountain black-eye (Chlorocharis): Ecology and Natural History. Sarawak Museum Journal, 6: 663-687.
Harrison, T. (1956). A new mountain black-eye (Chlorocharis) from North Borneo. Sarawak Museum Journal, 8; 516-521.

Mackinnon, J. \& Phillipps, K. (1993). A field guide to the birds of Borneo, Sumatra, Java and Bali. Oxford: Oxford University Press, pp. 491

Mees, G.F. (1955). The mountain black-eye (Chlorocharis): Ecology and Natural History. Sarawak Museum Journal, 6: 663-687.

Miskimen, M. (1980). Red-winged blackbirds: Pigmentation in epaulet of females. Ohio Journal of Science, 80 (5): 236.

Proctor, N.S. \& Lynch, P.J. (1993). Manual of Ornithology. Avian Structure and Function. New Haven and London Yale University Press, pp. 340

Price, T.D. (2006) Review: Phenotypic plasticity, sexual selection and the evolution of colour patterns. The Journal of Experimental Biology, 209: 2368-2376.

Smythies, B.E. (1999). The birds of Borneo fourth edition. Kota Kinabalu : Natural History Publications (Bomeo) Sdn. Bhd., pp. 853

Steinheimer, F.D. (1999). The Mountain Blackeye (Chlorocharis emiliae) as a rhododendron flower visitor on Mount Kinabalu, Sabah, Malaysia. Forktail, 15: 100-101.

Stevens, M., Stoddard, M.C. \& Higham, J.P. (2009). Studying primate colour: Towards visual systemdependant methods. International Journal of Primatology, 30: 893-917.

Vanderwerf, E.A. (2001). Two year delay in plumage of male and female 'Elepaio'. The Condor, 103: 756-766.

Winker, K. (2000). Obtaining, preserving, and preparing bird specimens. Journal of Field Ornithology, 71: 250-297.

Wood, D.L. \& Wood, D.S. (1972). Numerical colour specification for bird identification: Iris colour and age in fall migrants. Bird Banding, 43 (3): 182190. 